\title{
Interactive comment on "The contribution of air temperature and ozone to mortality rates during hot weather episodes in eight German cities during the years 2000 and 2017" by Alexander Krug et al.
}

Alexander Krug et al.

a.krug@tu-berlin.de

Received and published: 9 July 2020

The Responses to Referee \#2 comments are provided in the attached supplement.

Please also note the supplement to this comment:

https://www.nat-hazards-earth-syst-sci-discuss.net/nhess-2020-91/nhess-2020-91- 
2020-91, 2020.

NHESSD

Interactive

comment

Printer-friendly version

Discussion paper 